\title{
Blended Learning: Revealing Its Transformative Potential and Practice During the Covid-19 Era
}

\author{
Alfi Hidayatu Miqawati* \\ Language, Communication, and \\ Tourism Department \\ Politeknik Neger Jember \\ Jember, Indonesia \\ alfi_hidayatu@polije.ac.id
}

\author{
Fitri Wijayanti \\ Language, Communication, and \\ Tourism Department \\ Politeknik Neger Jember \\ Jember, Indonesia \\ fitri@polije.ac.id
}

\begin{abstract}
The purpose of this paper is to provide an ample discussion of the transformative potential and practice of blended learning in the context of the challenges faced by teachers in teaching during the Covid-19 era. This study deployed qualitative design with several data collecting methods; observation, interview, documentation, and library study. The results showed that, because of the pandemic, a shift to the need to restructure students learning' activities and experience occurs transformative potential and practice of blended learning are analyzed. In addition, administrative and leadership issues (including policies) are addressed. The conclusion is that blended learning is in line with the values of traditional learning in higher education institutions and has provided a significant contribution to the efficiency of meaningful learning experiences. In addition, further studies regarding research and developments on different blended learning models and their effectiveness are needed.
\end{abstract}

Keywords—blended learning, pandemic, practice, higher education

\section{INTRODUCTION}

The emergence of industry 4.0 has changed the way people carry out their activities. [1] stated that people will live in global uncertainty, therefore, they must be able to predict a fast-changing future. As part of the global community, we must respond to this condition and make it an opportunity. One of the ways that this can be done is through the promotion of the three main literacy; digital, technology, and people. In short, to create competitive graduates, the use of ICT cannot be ignored. Because students have different learning styles and strategies, teachers need to vary their instruction to facilitate students and make them more motivated and actively involved in the class. [2] explained that with the demands of technological development, especially in the face of the 4.0 industrial revolution, teachers need to consider all the possibilities and benefits that can be obtained by using different resources during their classroom teaching. Therefore, finding an effective learning model is a challenge for educators.

With so many platforms and applications that can be used, teachers can take advantage of various online media. However, online learning cannot be separated from the role of teachers as facilitators. Therefore, face to face learning is also needed. This combination of online and face-to-face learning is called blended learning.
Blended learning models deployed by teachers are various. There are three blended learning models that have developed, supplemental, replacement, and emporium. The first model, supplemental, is a blended learning model that uses traditional learning structures and uses technology-based sources as supplements. Despite the use of technology, this does not change the structure of learning. Students learn and receive learning materials online, but they still meet teachers in faceto-face learning like traditional learning. The second model, replacement, is a model that replaces several face-to-face class meetings online, through interactive activities. Some of the main differences in this model are that online resources are integrated into the learning experience and there is also online communication. There are also online resources to learn from and face-to-face activities that are interactive and collaborative. In the third model, the emporium is a model that replaces all face-to-face class meetings with a learning portal. The portal provides access to online materials, online consultations, and online support. In other words, students' and teachers' communication completely depends on the internet connection [3], [4], [5].

There are many research results stating that blended learning is very useful in increasing the effectiveness of learning ([6], [7]). Previous research conducted by [8] also showed positive results regarding the use of blended learning in English learning. This study was conducted to investigate the effects and outcomes of three learning models (face-toface class, e-learning, and blended learning on students' scores on four language skills, namely writing, listening, speaking, and reading (vocabulary). Specifically, students who get blended learning treatment (a combination of face-to-face classes and e-learning) show the highest achievement results compared to the other two learning models, so it can be said that the application of blended learning in learning English is more effective to implement.

Before the Covid-19 era, face-to-face meetings between teachers and students were common and teachers with ample technology support employed supplemental and/or replacement blended learning. However, because of the Covid 19, teachers around the globe are experiencing an unprecedented and unique context - with no other choices other than to shift the traditional classroom setting to digital mode to facilitate the teaching and learning process. Not all teachers are ready and well-equipped with technological practices and familiar with platforms for remote teaching. 
These global digital instruction shifts, especially in the early stages of the Covi19 necessitated abut instantaneous provision of teacher professional development as well as students upgrading skills for full blended learning since they had little to no experience with the approach [9]. Based on the situation, this study aimed at discussing transformative potential and practice of blended learning in the context of the challenges faced by teachers in teaching during the Covid-19 era at Politeknik Negeri Jember. However, the discussion is limited to the context that occurred in a vocational higher education setting at Politeknik Negeri Jember.

\section{METHOD}

This study deployed a qualitative design. Three data collection methods were taken to gain the data of this study namely; (1) methodical observation of Politeknik Negeri Jember Learning Management System, (2) interviews with course and unit coordinators ( 3 course coordinators and 1 unit coordinator), (3) documentation, and (4) library studies. The data collection process took place at Politeknik Negeri Jember East Java, Indonesia. To gain the validity of the data, the triangulation was conducted by doing source of data triangulation. The data obtained were then analyzed and presented descriptively to answer the research objective.

\section{FINDINGS AND DISCUSSION}

The teaching and learning processes at the Politeknik Negeri Jember were conducted in many different ways. Prior to the pandemic, the teaching and learning process at the Jember State Polytechnic mostly adopted traditional learning, namely face-to-face interaction between teachers and students in every lecture activity. Only few teachers take advantage of the Learning Management System (LMS), which is managed by the Technical Implementation Unit (UPT) of Technology, Information and Communication. However, since the Covid19 has emerged, several actions were taken to address and prevent the spread of the Covid19 virus. Firstly, following the policy from the Indonesian central government to carry out lecture activities online, Politeknik Negeri Jember took several strategic actions and issued several policies so that learning outcomes can be maximally achieved.

Based on the results of document analysis, at the beginning of the Covid19, the director of the Politeknik Negeri Jember through the vice director of academic affairs issued a circular letter stating that all lecturing and practicum activities were carried out online and teachers were allowed to choose the platforms that they were familiar with and thought to be effective in supporting the achievement of the students' competence, including the optimization of LMS application. However, in the following semester (odd semester of 2020/2021 academic year), there was a circular letter update stating that all teachers were suggested to utilize LMS since the students got confused with many different platforms that their teachers used. The condition also led to many other problems, such as internet data needs, cellphone memory limit, bandwidth requirements, and so on. It also said the teachers were required to adopt more various teaching methods and user-friendly media or platforms, including blending the use of synchronous and asynchronous ones. Thus, it can be concluded that the emporium model of blended learning was applied.
Furthermore, the results of observations at LMS State Polytechnic of Jember showed that there were many transformative changes and opportunities created by blended learning. At the start of the online learning in the Covid19 era, not all teachers used LMS. Some chose to use WhatApp group chat or email to teach. However, because of limitations created by WhatsApp, email, and LMS a mix between synchronous and asynchronous platform use was then carried out. Teachers who did not master how to operate synchronous and asynchronous platforms, such as LMS and Zoom were trained. This was one of the most leading learning transformations because everything was done online and it provided many opportunities for teachers and students to carry out selfdevelopment related to mastery and improvement of technological literacy. The findings supported [10] that a lot of academic institutions that were earlier reluctant to change their traditional pedagogical approach had no option but to shift entirely to online teaching-learning.

The results of the interviews indicated that online learning also had many positive and negative impacts. The positive impacts were that 1) learning could be carried out flexibly, 2) students could access resources anytime, 3) it enhanced students' learning experience, 4) it provided a supportive learning environment. It is in line with [11] that blended learning becomes experts' recommendation for the development of learning and teaching practices since it can promote students' learning experience.

In addition, several teachers mentioned that the emporium blended learning conducted both synchronously and asynchronously promote students' engagement and motivation. The finding support [12] that the use of technology can encourage students to engage in classroom activities and monitor their own learning.

However, some of the challenges that must be taken into an account is that how to maximize the students' engagement and minimize their boredom while attending the full online class since they did not interact physically with their peers and they have different learning environment at home. A study conducted by [13] has also stated that purely online learning does not outperform traditional face-to-face instruction or supplemental blended learning. However, on the whole, this blended learning is very useful, especially in being an alternative solution for existing conditions until the Covid19 is over.

\section{CONCLUSION}

Teachers and students have faced a tremendous shift in the terms of teaching and learning mode because of the Covid19 pandemic. They were urged to adapt to the situation and find the most relevant way to hold a teaching and learning process. This study was limited to the context of the implementation of blended learning at Politeknik Negeri Jember East Java, Indonesia. Emporium blended learning became the most adapted model to adjust the current situation at Politeknik Negeri Jember. The model could help teachers promote their students' competence achievement, regardless the absence of physical interaction. However, several challenges occurred as a consequence of the implementation. Therefore, further studies related to the effectiveness or the development of other blended learning models are suggested. 


\section{ACKNOWLEDGMENT}

This publication was supported by Grant Number 415/PL.17/PG/2020 from DIPA Politeknik Negeri Jember. Its contents are solely the responsibility of the authors and do not necessarily represent the official views of Politeknik Negeri Jember.

\section{REFERENCES}

[1] Ghufron, G. Industrial Revolution 4.0: Challenges, Opportunity, and Solution (Revolusi Industri 4.0: Tantangan, Peluang, dan Solusi Bagi Dunia Pendidikan). In National Seminar and Multidisciplinary Panel Discussion on Research Results and Community Empowerment 2018) (Seminar Nasional dan Diskusi Panel Multidisiplin Hasil Penelitian dan Pengabdian Kepada Masyarakat 2018 (Vol. 1, No. 1). (2018, September).

[2] Chien-Hung, L., Yu-Chang, L., Bin-Shyan, J., \& Yen-Teh, H. Adding social elements to game-based learning. International Journal of Emerging Technologies in Learning, 9(3), 12-15. doi:10.3991/ijet.v9i3.3294. (2014).

[3] Caraivan, Luiza. "Blended learning: from concept to implementation." Euromentor Journal-Studies About Education 04 (2011): 119-126.

[4] Mestan, Kemran. "Create a fine blend: An examination of institutional transition to blended learning." Australasian Journal of Educational Technology 35.1 (2019).

[5] Graham, Charles R., Curtis R. Henrie, and Andrew S. Gibbons. "Developing models and theory for blended learning research." Blended learning: Research perspectives 2 (2013): 13-33
[6] Al Zumor, A. W. Q., Al Refaai, I. K., Eddin, E. A. B., \& Al-Rahman, F. H. A. EFL Students' Perceptions of a Blended Learning Environment: Advantages, Limitations and Suggestions for Improvement. English Language Teaching, 6(10), 95-110. (2013).

[7] Lee, J. Y., \& Lee, C. H. Students' perspectives and the effectiveness of blended learning in L2 listening at university level. MultimediaAssisted Language Learning, 15(1), 59-89. (2012).

[8] Kurucova, Z, Medová, J \& Tirpakova, A. The effect of different online education modes on the English language learning of media studies students. Cogent Education, 5:1, 1523514. (2018).

[9] Lockee, Barbara B. "Shifting digital, shifting context:(re) considering teacher professional development for online and blended learning in the COVID-19 era." Educational Technology Research and Development (2020): 1-4.

[10] Dhawan, Shivangi. "Online learning: A panacea in the time of COVID19 crisis." Journal of Educational Technology Systems 49.1 (2020): 522.

[11] Poon, Joanna. "Blended learning: An institutional approach for enhancing students' learning experiences." Journal of online learning and teaching 9.2 (2013): 271-288.

[12] Miqawati, Alfi Hidayatu. "Pronunciation Learning, Participation, And Attitude Enhancement Through Mobile Assisted Language Learning (Mall)." English Review: Journal of English Education 8.2 (2020): 211-218.

[13] Means, Barbara, et al. "The effectiveness of online and blended learning: A meta-analysis of the empirical literature." Teachers College Record 115.3 (2013): 1-47. 